\title{
Seasonality and mycorrhizal colonization in three species of epiphytic orchids in southeast Mexico
}

\author{
Vincenzo Bertolini ${ }^{1,3}$, Jesús Cruz-Blasi ${ }^{2}$, Anne Damon ${ }^{1}$ and Javier Valle Mora ${ }^{1}$
}

Received: November 27, 2013. Accepted: April 28, 2014.

\begin{abstract}
Orchids establish symbiosis with Rhizoctonia mycorrhizal fungi, forming the characteristic pelotons within the cells of the root cortex. Under natural conditions, terrestrial and epiphytic orchids have different levels of dependence upon the fungal symbiont, although various authors have mentioned that once orchid plants reach maturity the interaction becomes weaker and intermittent. Recent evidence shows that in some epiphytic orchid species mycorrhization is constant and systematic. In three species of wild orchids from southeast Mexico, we show that mycorrhization is systematically present in roots of different ages, in the wet and dry seasons. We demonstrate that the volume of the root that is colonized depends upon the quantity of rainfall and the diameter of the root, and that rainfall also determines the presence of fresh, undigested pelotons. In very thin roots, mycorrhizal colonization occupies a considerable proportion of the cortex, whereas in thicker roots the proportion of the volume of the root cortex colonized is lower.
\end{abstract}

Key words: Epidendrum stamfordianum, Erycina crista-galli, Stelis quadrifida, mycorrhization intensity

\section{Introduction}

The nutritional role of mycorrhizae in the Orchidaceae has been well documented for temperate, terrestrial species, and especially those native to North America, Europe and parts of Asia and Australia (Rasmussen 1995), including photosynthetic species with partial mycotrophy (mixotrophy) and obligate mycoheterotrophs that depend upon the symbiosis to complete their life cycle (Leake 1994; Gebauer \& Meyer 2003; Julou et al. 2005; Girlanda et al. 2006). However, since the 1970s, the discussion has focused upon epiphytic species, which represent $80 \%$ of the Orchidaceae and dominate neotropical regions (Kottke et al. 2006; Otero et al. 2007; Martos et al. 2012; Valadares et al. 2013).

It has been assumed that, for epiphytic orchids, dependence upon mycorrhizae is probably not obligate during the first stages of germination, for three reasons: some orchid seeds contain small drops of lipids and protein in the embryo; the rapid assimilation of simple nutrients in in vitro culture media; and after imbibing water, and when exposed to light, the seeds rapidly pass to a photosynthetic state (Arditti 1992). Nevertheless, studies on symbiotic germination in vitro demonstrate dependence upon the mycorrhizae for the differentiation and development of each life stage, and that growth ceases and the plant eventually dies in the absence of a mycorrhizal symbiont (Zettler et al. 1998; Markovina \& McGee 2000; Pereira et al. 2005a).

Results of the analysis of canopy "soils" indicate that they are rich in organic material and nutrients, mainly $\mathrm{NO}_{3}$, $\mathrm{NH}_{4}$ and $\mathrm{PO}_{4}$, which are, however, difficult to assimilate due to acidity and the particular nutrient balance of the medium (Lesica \& Antibus 1990; Nadkarni \& Matelson 1991). In addition, the surface area of the roots of epiphytic orchids is small in proportion to the biomass of the stems and leaves (Benzing \& Ott 1981). Therefore, epiphytic orchid roots have evolved a diversity of functions, including an epidermal structure (velamen) to facilitate the rapid absorption and retention of water; the differentiation of anatomic structures (tilosomes) to reduce transpiration; and the photoassimilation of $\mathrm{CO}_{2}$ via the photosynthetic routes $\mathrm{C}_{3}$, CAM or both. As mentioned by Benzing \& Friedman (1981), it can be assumed that "a combination of phototrophy and mycotrophy should be an advantage for an epiphyte" (Rasmussen \& Whigham 2002; Julou et al. 2005; Girlanda et al. 2006). Nevertheless, studies on mycorrhizal colonization in mature, epiphytic orchids have presented discrepancies, various authors concluding that mycorrhizal colonization is occasional (Hadley \& Williamson 1972; Lesica \& Antibus, 1990), whereas more recent studies have indicated systematic colonization in species from Florida,

\footnotetext{
${ }^{1}$ El Colegio de la Frontera Sur (ECOSUR), Carretera Antiguo Aeropuerto Km 2.5 Apdo. Postal 36, Tapachula, Chiapas, C.P. 30700, México.

${ }^{2}$ Servicio Nacional de Sanidad, Inocuidad y Calidad Agroalimentaria (SENASICA), Municipio Libre No. 377 Col. Santa Cruz Atoyac, Deleg. Benito Juárez, C.P. 03310 México, D.F.

${ }^{3}$ Author for correspondence: vbertolini@ecosur.mx
} 
Singapore, Costa Rica and Brazil (Benzing 1982; Goh et al. 1992; Rivas-Rossi et al. 1998; Pereira et al. 2005b). Despite valuable contributions toward the understanding of the importance of mycotrophy in epiphytic orchids, the intensity of colonization has not been sufficiently studied, and one way to do that is to estimate the volume of the root system colonized (Rasmussen \& Whigham 2002). This is particularly relevant for epiphytic species with extreme reduction of stems and leaves wherein the root biomass accounts for 95\% of the total (Benzing \& Ott 1981). The aim of this study was to characterize the relationship between the intensity of mycorrhizal colonization and the diameter and length of the roots, in the wet and dry seasons, for three species of epiphytic orchids native to southeast Mexico.

\section{Materials and methods}

\section{Study site}

The root samples were collected from plants within dense populations of each species, at four sites within the Sierra Madre mountain range, in the state of Chiapas, in southeast Mexico (Tab. 1), in a region known as Soconusco. The region is characterized by remnant fragments of tropical moist broadleaf forest at lower elevations and tropical montane cloud forest at higher elevations, now mostly given over to extensive areas of coffee plantations shaded by native species and a diversity of Inga sp. (Fabaceae) (Damon \& Colín-Mártinez 2005). As shown in Tab. 1, the climate of the region is warm and humid, with abundant rain in summer that increases with elevation (INEGI 2011).

\section{Biological material}

Three orchid species were studied: Epidendrum stamfordianum Bateman, Stelis quadrifida (La Llave \& Lex.) R. Solano \& Soto Arenas and Erycina crista-galli (Rchb.f.) N.H. Williams \& M.W. Chase, and the majority were found growing upon mature trees of Roseodendron donnell-smithii (Rose) Miranda, Tabebuia rosea (Bertol.) Bertero ex A. DC. (Bignoniaceae) and Enterolobium cyclocarpum (Jacq.) Griseb. (Fabaceae), in coffee (Coffea arabica L.) and cocoa (Theobroma cacao) L. plantations.

Epidendrum stamfordianum has large pseudobulbs and few, long, thick roots; Stelis quadrifida is a smaller sized plant with no pseudobulbs and roots that are numerous, grouped, short and thin, whereas Erycina crista-galli is a miniature twig epiphyte, now mostly found growing upon coffee bushes and has long, thin roots that are few in number. The roots of all three species grow along the surface of the bark, but in the case of S. quadrifida the roots were also seen to penetrate slightly into the external, decomposing layer of the bark.

The roots were collected during the dry season in February and March and in the wet season in August and September. Three healthy and complete roots of different sizes were sampled per orchid plant, the shortest (youngest) and longest (oldest) roots were sampled along with a medium sized root. Two plants per site were sampled for each species. The roots were carefully removed from the bark, placed into labeled, plastic bags, packed with ice and taken to the laboratory (Tab. 2).

The length of each root and the diameter of each section were measured with a Vernier caliper. Due to the differences in the size of the roots among the three species (Epidendrum stamfordianum, Erycina crista-galli and Stelis quadrifida, with maximum lengths of $92.0,6.5$ and $11.0 \mathrm{~cm}$ and average diameters of 4.0, 0.8 and $0.8 \mathrm{~mm}$, respectively), the number of sections taken from each root was standardized. A series of three sequential, transverse sections were taken within the first $3.0 \mathrm{~mm}$ of the apical meristem of each of the roots. Then, from the base to the tip of the root, sections were taken at intervals of approximately 1.5 times the diameter of the root; every $1.2 \mathrm{~mm}$ for S. quadrifida and E. crista-galli; and every $6.0 \mathrm{~mm}$ for E. stamfordianum.

Mycorrhization was evaluated using a modified version of the methods described by Goh et al. (1992) and Rasmussen \& Whigham (2002). Thin roots were wrapped in a layer of parafilm for support and rigidity. Sections from each root were mounted onto a slide, in order from tip to base, and then stained with Acid Fuchsin $(0.01 \%$ w/v in lactic acid-glycerol-distilled water 14:1:1 v/v/v) and mounted in Polyvinyl alcohol-lactic acid-glycerol, for observation with an optic microscope at $\times 40$ magnification. Mycorrhization intensity was obtained for each section, using six scales, representing $0,12.5,25.0,50.0,75.0$ and 100\% of the cortical area, according to Rasmussen \& Whigham (2002). Undefined pelotons with intact hyphae, visible at $\times 40$ and slightly stained, were classified as live and recently penetrated into the cell. Well-defined, dense, heavily stained

Table 1. Geographic and macroclimatic characteristics of the collection sites.

\begin{tabular}{ccccccc}
\hline Colection site & Lat. & Long. & Altitude $(\mathrm{m})$ & Temp. (av./year) $\left({ }^{\circ} \mathrm{C}\right)$ & $\begin{array}{c}\text { Precipitation } \\
(\mathrm{mm} / \text { year })\end{array}$ & Dry season $(<60 \mathrm{~mm} /$ year $)$ \\
\hline Tuzantán & $15^{\circ} 06^{\prime} \mathrm{N}$ & $92^{\circ} 24^{\prime} \mathrm{W}$ & 118 & 28 & 2668 & December - April \\
Izapa & $14^{\circ} 58^{\prime} \mathrm{N}$ & $92^{\circ} 09^{\prime} \mathrm{W}$ & 482 & 26 & 4660 & December - February \\
Unión Roja & $15^{\circ} 02^{\prime} \mathrm{N}$ & $92^{\circ} 12^{\prime} \mathrm{W}$ & 500 & 22 & 4800 & December - February \\
Santo Domingo & $15^{\circ} 01^{\prime} \mathrm{N}$ & $92^{\circ} 06^{\prime} \mathrm{W}$ & 900 & 22 & 4800 & December - February \\
\hline
\end{tabular}


Table 2. Biological material and collection sites.

\begin{tabular}{|c|c|c|c|c|c|c|}
\hline Species & Site & Plants/site & Shortest roots / plant & Medium roots /plant & Longest roots /plant & Total roots \\
\hline \multirow{2}{*}{ Epidendrum stamfordianum } & Tuzantán & 2 & 1 & 1 & 1 & 6 \\
\hline & Unión Roja & 2 & 1 & 1 & 1 & 6 \\
\hline \multirow{2}{*}{ Erycina crista-galli } & Santo Domingo & 2 & 1 & 1 & 1 & 6 \\
\hline & Unión Roja & 2 & 1 & 1 & 1 & 6 \\
\hline \multirow{2}{*}{ Stelis quadrifida } & Unión Roja & 2 & 1 & 1 & 1 & 6 \\
\hline & Izapa & 2 & 1 & 1 & 1 & 6 \\
\hline
\end{tabular}

pelotons without visible hyphae were classified as dead. Cells that showed evidence of recent recolonization were also classified as live.

To analyze the correlation between the percentage of fresh pelotons and colonization, a non-parametric softener was adjusted, considering the factors "species", "season" (wet and dry) and "length of root". The factor "length of root" was classified as L - longest (Epidendrum stamfordianum: 50-90 cm; Erycina crista-galli: $3.5-7 \mathrm{~cm}$; Stelis quadrifida: 5-11 cm), M - medium (E. stamfordianum: $15-50 \mathrm{~cm}$; E. crista-galli: $1.5-3.5 \mathrm{~cm}$; S. quadrifida: $2-5 \mathrm{~cm}$ ) and $\mathrm{S}$ - shortest (E. stamfordianum: $5-15 \mathrm{~cm}$; E. crista-galli: $0.2-1.5 \mathrm{~cm}$; S. quadrifida: $0.5-2 \mathrm{~cm}$ ).

The relation between mycorrhization intensity and root diameter was also analyzed using a non-parametric softener. The percentage colonization for each species was analyzed using the non-parametric Kruskal-Wallis test. The statistical analysis was carried out with the software $\mathrm{R}$, version 3.0.1 (R Development Core Team 2013).

\section{Results and discussion}

Considering the combination of the three types of roots (L, M and S), all three orchid species had a significantly higher percentage of the volume of the root cortex colonized by mycorrhizae in the wet season (Kruskal-Wallis test, Epidendrum stamfordianum: $\mathrm{W}=58421, p<2.2 \mathrm{e}-16$; Erycina crista-galli $\mathrm{W}=8956.5, p<2.2 \mathrm{e}-16$; Stelis quadrifida: $\mathrm{W}=9845.5, p<2.2 \mathrm{e}-16$ ), as shown in Fig. 1. Analysis of mycorrhization intensity in function of the length of the roots ( $\mathrm{L}, \mathrm{M}$ and $\mathrm{S}$ ), which is related to root age, also demonstrated significant differences according to the season. The mycorrhization of the shortest/youngest (S) roots was shown to be either particularly dependent upon the humidity of the wet season (Fig. 2 and Tab. 3) or simply reflecting the time necessary for mycorrhizal colonization.

New roots are usually formed toward the end of the dry season, in anticipation of the coming rains, and new root formation marks the end of a rest period typical of epiphytic orchids even in tropical climates. At first, these new roots have little or no mycorrhizal colonization, which was also observed in the growing tips of the oldest roots. In the wet season, roots were seen to have more fresh pelotons than in the dry season. In the dry season, fresh pelotons were found only in Erycina crista-galli, and there were far fewer than in the wet season (Fig. 3).

The Rhizoctonia group is characterized by dispersion by sclerotia in liquid water (rain). When climate conditions are adverse, the mycelium develops the sclerotium to survive during these periods. Therefore, the water represents a fundamental medium for dispersing these structures, and without rains or adequate humidity the sclerotium does not germinate unless in contact with the host plant. Ogoshi (1996) mentions that Rhizoctonia solani mycelium was found in the soil in the autumn and spring, whereas it was almost absent in summer (the hot, dry period in temperate regions). In the same way, in tree branches, if the humidity is too low, the probability of association between orchid roots and mycelium is lower during the dry season in tropical regions. In contrast, the wet season induces the development of orchid roots, which form as well-hydrated vegetal soft tissues, allowing the penetration of mycelium.

Diameter was a determining factor for the intensity of mycorrhizal colonization. The intensity of colonization was greater in thin roots, which could be due to a relatively higher proportion of available root surface for mycorrhizal colonization in relation to volume, and the highest percentage colonization in this study was observed in the thin roots of the twig epiphyte Erycina crista-galli (Fig. 4). A further implication could be that orchid species with thin roots absorb less from the surrounding environment and are more dependent upon mycorrhizae. In the case of E. crista-galli, the particularly extreme, variable and stressful xerophytic conditions of the microhabitat occupied by this miniature orchid could have resulted in greater dependence upon mycorrhizal fungi.

Stelis quadrifida and Erycina crista-galli are mediumand small-sized species, respectively, both having thin roots, which maintain greater contact with the surface of the substrate, whereas a substantial proportion of the thick roots of Epidendrum stamfordianum remain in contact with the air. Colonization was seen to approach $100 \%$ in sections of the roots of the two species with thin roots, whereas for E. stamfordianum, which has thick roots, colonization did not exceed $60 \%$ (Fig. 4), further supporting the suggestion 


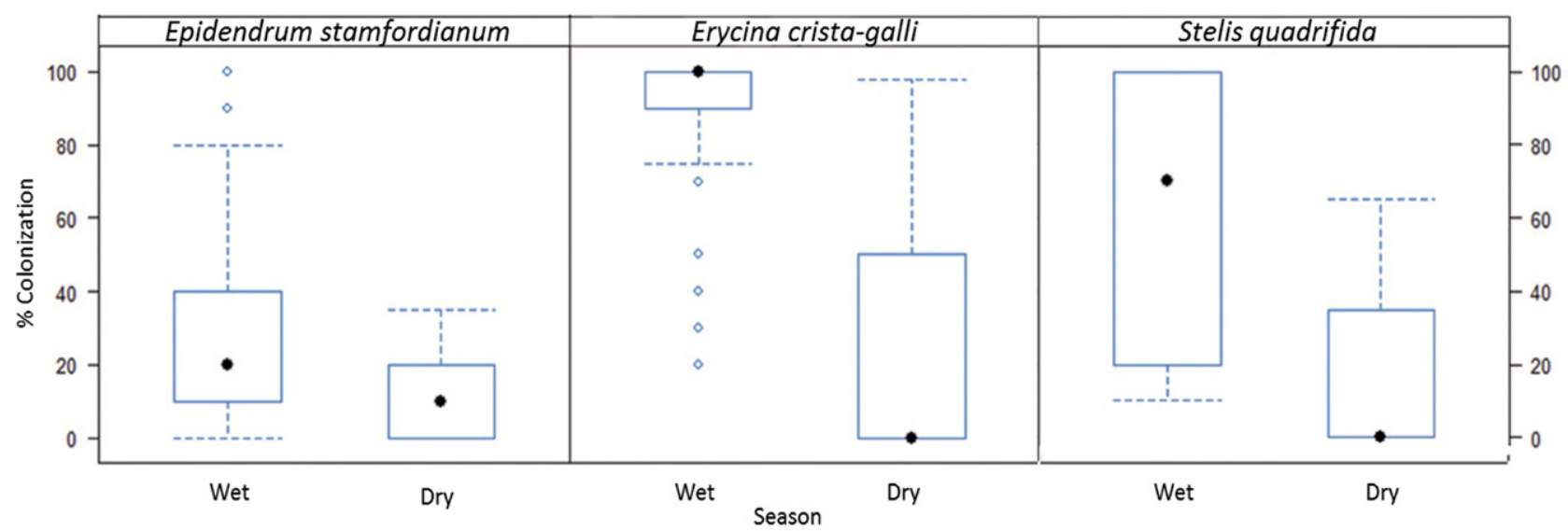

Figure 1. Comparison of the mycorrhizal percentage in the roots of three species of epiphytic orchids, in the wet and dry season, in southeast Mexico.

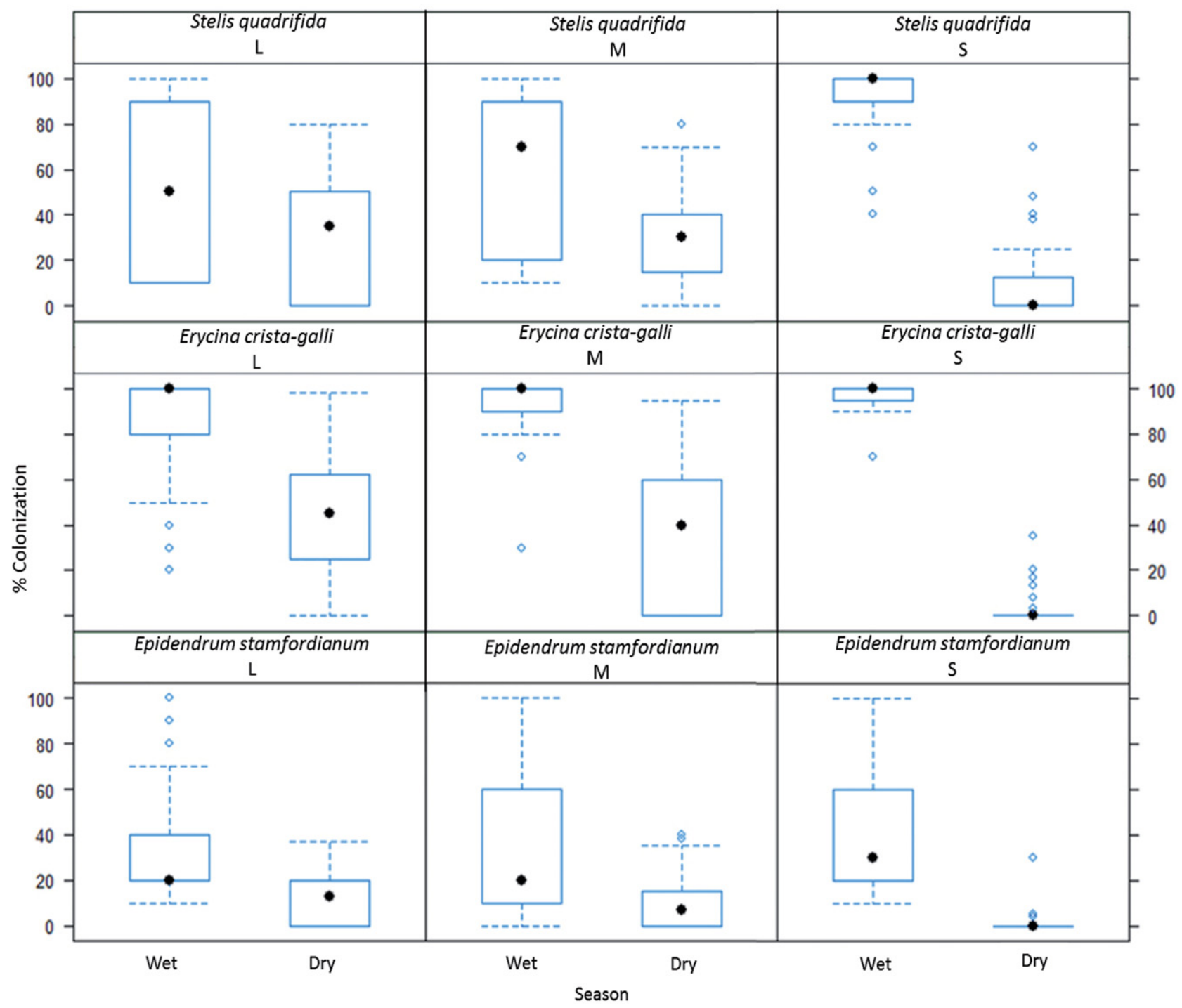

Figure 2. Comparison of the proportional mycorrhizal colonization of three classes of roots (L: longest/oldest; M: medium; S: shortest/youngest) of epiphytic orchids, in the wet and dry season, in southeast Mexico. 
Table 3. Comparison of the intensity (\%) of mycorrhizal colonization of three classes of roots (L: longest/oldest; M: medium; S: shortest/youngest) of epiphytic orchids, in the wet and dry season, in southeast Mexico, with the non-parametric Kruskal-Wallis test.

\begin{tabular}{lccc}
\hline & Specie & W* value & P value \\
\hline Epidendrum stamfordianum & L & 54258 & $2.20 \mathrm{e}-16$ \\
& M & 12971 & $2.20 \mathrm{e}-16$ \\
& S & 2340 & $2.20 \mathrm{e}-16$ \\
Erycina crista-galli & L & 3896 & $4.09 \mathrm{e}-14$ \\
& M & 3253.5 & $2.20 \mathrm{e}-16$ \\
& S & 1219 & $6.62 \mathrm{e}-15$ \\
\hline & L & 5050 & $4.60 \mathrm{e}-05$ \\
& M & 3200.5 & $3.22 \mathrm{e}-06$ \\
\hline
\end{tabular}

*All comparisons have 1 degree of freedom

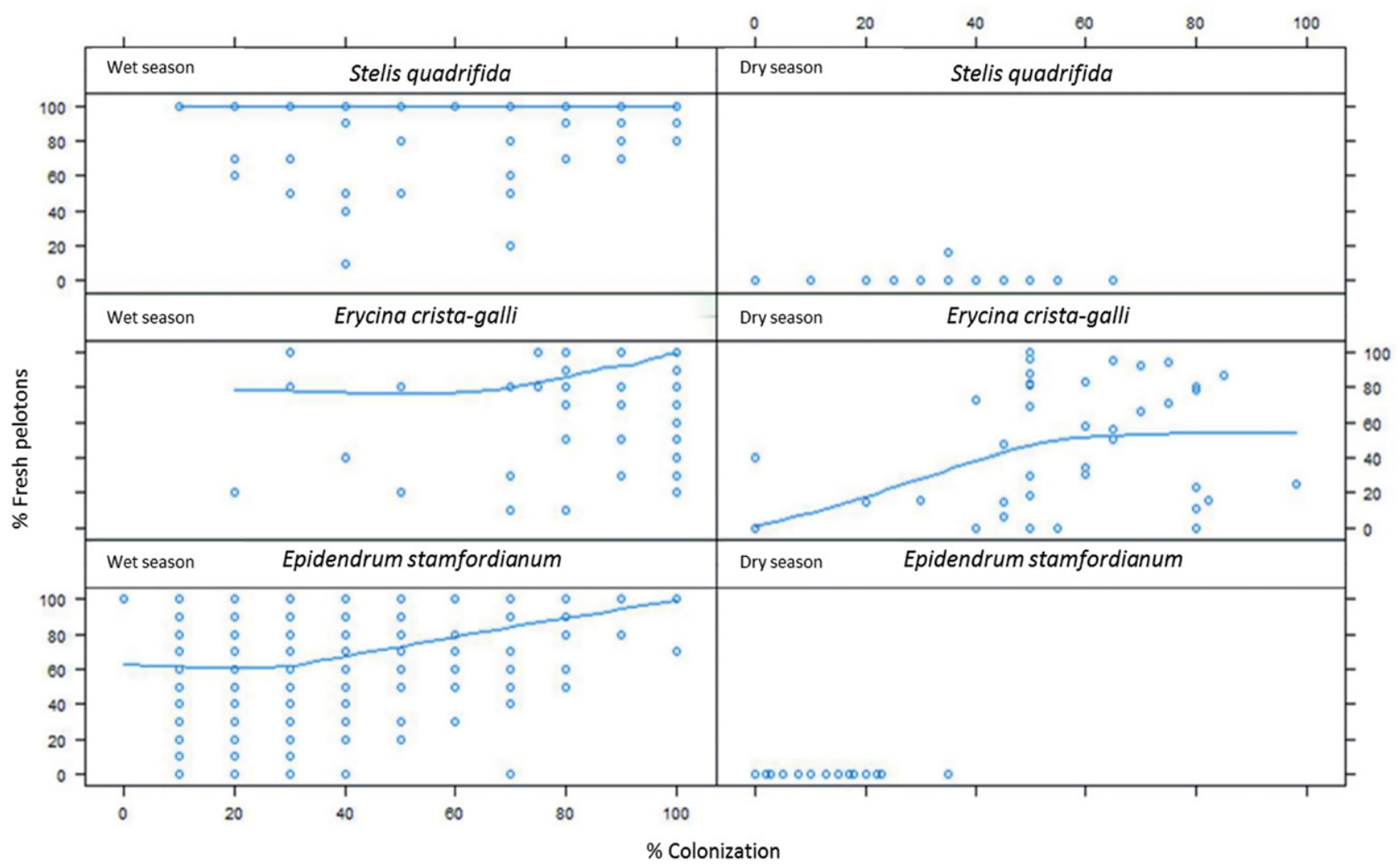

Figure 3. Comparison of the percentage of fresh pelotons in the roots of epiphytic orchids, in the wet and dry season, in southeast Mexico.

that orchid species with thin roots are more dependent upon mycorrhizae. In the two species with thin roots, mycorrhizal colonization was uniform throughout, which was not the case for the thick roots of E. stamfordianum, in which colonization was observed mostly in the areas of the root that had been in contact with the substrate.

The only roots areas seen to be free of mycorrhizal fungi were the apical meristem, the basal area of the main root and the ramifications. The new sections of growing roots originate from the vascular cambium, which is not host to mycorrhizal fungi, and mycorrhization occurs as the roots enter in contact with the substrate or other mycorrhizal roots, and in the latter case then acquire the same pattern of colonization. Similarly, the process of colonization is influenced by the extent and distribution of organic detritus and the extension of the roots into these areas, reaching 100\% 


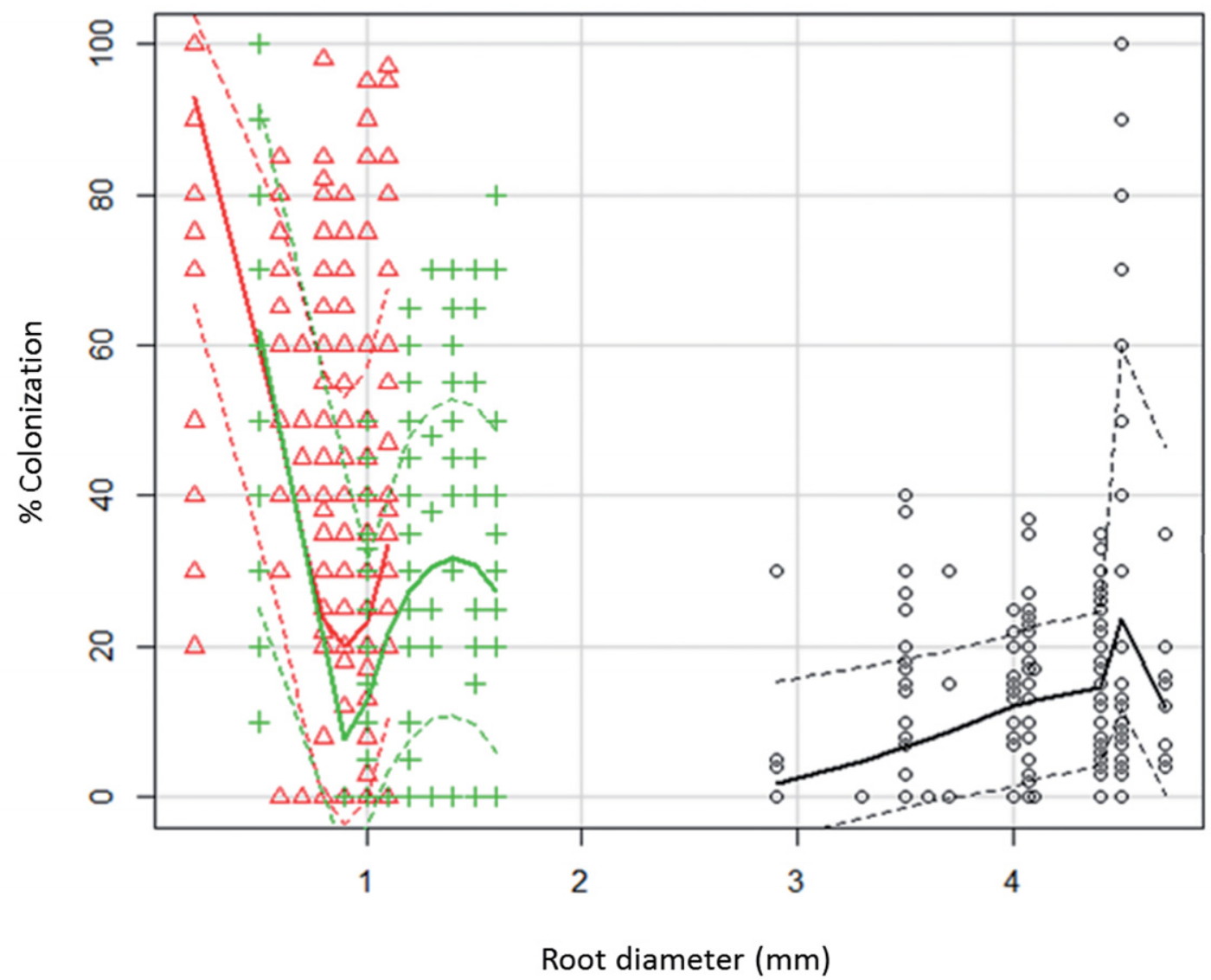

Figure 4. Relationship between mycorrhization intensity and root diameter, for three species of epiphytic orchids in southeast Mexico: Epidendrum stamfordianum $\left({ }^{\circ}\right)$; Erycina crista-galli $(\Delta)$; and Stelis quadrifida $(+)$.

colonization. Further studies should analyze the mechanisms by which orchid cells and fungal hyphae recognize each other, the process of penetration and colonization and the control of fungal development within orchid root cells, as well as why some areas are colonized and others are not.

Mycorrhization was found in the roots of all the plants sampled in this study, although in varied proportions and quantities and with seasonal fluctuations, supporting the results in the literature that consider the mycorrhizal colonization of the roots of epiphytic orchids as systematic (Benzing 1982; Goh et al. 1992; Rivas-Rossi et al. 1998; Pereira et al. 2005b). However, the affirmation of Hadley \& Williamson (1972) that "in epiphytic orchids infection is spasmodic and confined to a small proportion of cells in the root cortex" was based on the quantification of the numbers of cells colonized in a few root sections. The results obtained by Goh et al. (1992) and in the present study show that the intensity of colonization can vary between $0 \%$ and almost $100 \%$ along the length of the root. To guarantee an unbiased and realistic picture of mycorrhizal colonization, samples should be taken at regular intervals along the entire length of the root. A better measure of the intensity of colonization is the volume of root colonized, considering the whole root, as demonstrated by Rasmussen \& Whigham (2002).

Our results suggest that the diameter of the roots of an epiphytic orchid is one of the factors that determine the percentage colonization of the root cortex by mycorrhizal fungi. However, Goh et al. (1992) and Pereira et al. (2005b) reported intense colonization, reaching $95 \%$, in the root cortex of the epiphytic orchids Dendrobium crumenatum Sw., Maxillaria marginata (Lindl.) Fenzl, Oncidium flexuosum Lodd and Oncidium varicosum Lindl., which have thin roots, as well as in that of Isochilus linearis (Jacq.) R. Br., which has thick roots.

\section{Conclusions}

The results of the present study show that the intensity of mycorrhizal colonization of the root cortex of three epiphytic orchids in southeast Mexico is continuous and systematic, with higher intensity and greater numbers of undigested, live pelotons in the wet season. Our results also show that, for the species studied, the intensity of mycorrhizal colonization is relatively greater on thin roots and in areas in contact with the substrate. 


\section{Acknowledgments}

This study received financial support from the Secretaria de Medio Ambiente y Recursos Naturales-Consejo Nacional de Ciencia y Tecnología (SEMARNAT-CONACYT, Department of the Environment and Natural Resources-National Council for Science and Technology; Grant no. 2002-C01-0697 for the Project "Restauración y aprovechamiento sustentable de las orquídeas del Soconusco, Chiapas, México"). We are grateful to María del Pilar Ortega Larrocea, of the Geology Institute of the Universidad Nacional Autónoma de México (UNAM, National Autonomous University of Mexico), for the valuable suggestions offered during the development of the study.

\section{References}

Arditti, J. 1992. Fundamentals of orchid biology. New York, USA, John Wiley \& Sons.. 613p.

Benzing, D.H. 1982. Mycorrhizal infection of epiphytic orchids in southern Florida. American Orchid Society Bulletin 51: 618-622.

Benzing, D.H. \& Friedman, W.E. 1981. Mycotrophy: its occurrence and possible significance among epiphytic Orchidaceae. Selbyana 5: 243-247.

Benzing, D.H. \& Ott, D.W. 1981. Vegetative reduction in epiphytic Bromeliaceae and Orchidaceae, its origin and significance. Biotropica 13: $131-140$

Damon, A. \& Colín-Martínez, H. 2005. El estado actual de las poblaciones de orquídeas en la región del Soconusco, Chiapas. Amaranto 3: 2-16.

Gebauer, G. \& Meyer, M. 2003. ${ }^{15} \mathrm{~N}$ and ${ }^{13} \mathrm{C}$ natural abundance of autotrophic and mycoheterotrophic orchids provides insight into nitrogen and carbon gain from fungal association. New Phytologist 160: 209-223.

Girlanda, M.; Selosse, M.A.; Cafasso, D.; Brilli, F.; Delfine, S.; Fabbian, R.; Ghignone, S.; Pinelli, P.; Segreto, R.; Loreto, F.; Cozzolino, S. \& Perotto, S. 2006. Inefficient photosynthesis in the Mediterranean orchid Limodorum abortivum is mirrored by specific association to ectomycorrhizal Russulaceae. Molecular Ecology 15: 491-504.

Goh, C. J.; Sim, A.A. \& Lim, G. 1992. Mycorrhizal associations in some tropical orchids. Lindleyana 7: 13-17.

Hadley, G. \& Williamson, B. 1972. Features of mycorrhizal infection in some Malayan orchids. New Phytologist 71: 1111-1118.

INEGI. 2011. Instituto Nacional de Estadística y Geografía. México. Tipos de climas en Chiapas. Available in: http://mapserver.inegi.org.mx/ geografia/espanol/estados/chis/climas.cfm?c=444\&e=04. Accessed in: 17 November 2012.

Julou, T.; Burghardt, B.; Gebauer, G.; Berveiller, D.; Damesin, C. \& Selosse, M.A. 2005. Mixotrophy in orchids: insights from a comparative study of green and nonphotosynthetic individuals of Cephalanthera damasonium. New Phytologist 166: 639-653.
Kottke, I.; Suárez, J.P.; Herrera, P.; Cruz, D.; Bauerhttp://rspb.royalsocietypublishing.org/content/early/2009/12/01/rspb.2009.1884.full - aff-1, R.; Haug, I. \& Garnica, S. 2006. Atractiellomycetes belonging to the 'rust' lineage (Pucciniomycotina) form mycorrhizae with terrestrial and epiphytic neotropical orchids. Mycological Research 110: 1257-1270

Leake, J.R. 1994. The biology of mycoheterotrophic ('saprophytic') plants. New Phytologist 127: 171-216.

Lesica, P. \& Antibus, R.K. 1990. The occurrence of mycorrhizae in vascular epiphytes of two Costa Rican rain forests. Biotropica 22: 250-258.

Markovina, A-L. \& McGee, P.A. 2000. Comparison of symbiotic and asymbiotic seed germination and plantlet development in Sarcochilus (Vandeae: Orchidaceae). Lindleyana 15: 68-72.

Martos, F.; Munoz, F.; Pailler, T.; Kottke, I.; Gonneau, C. \& Selosse. M.A. 2012. The role of epiphytism in architecture and evolutionary constraint within mycorrhizal networks of tropical orchids. Molecular Ecology 21: 5098-5109

Nadkarni, N.M. \& Matelson, T.J. 1991. Fine litter dynamics within the tree canopy of a tropical cloud forest. Ecology 72: 2071-2082.

Ogoshi, A. 1996. The genus Rhizoctonia. Pp. 1-9. In: Sneh, B.; Jabaji-Hare, S.; Neate, S.M. \& Dijst, G. (Eds.). Rhizoctonia species: Taxonomy, Molecular Biology, Ecology, Pathology and Disease Control. Netherlands, Springer.

Otero, J.T.; Flanagan, N.S.; Herre, E.A.; Ackerman, J.D. \& Bayman, P. 2007. Widespread mycorrhizal specificity correlates to mycorrhizal function in the neotropical, epiphytic orchid Ionopsis utricularioides (Orchidaceae). American Journal of Botany 94: 1944-1950.

Pereira, O.L.; Kasuya, M.C.M.; Rollemberg, C.L. \& Borges, A.C. 2005a. In vitro symbiotic seed germination of Oncidium flexuosum (Orchidaceae) by Rhizoctonia-like mycorrhizal fungi. Revista Brasileira de Ciência do Solo 29: 199-206.

Pereira, O.L.; Kasuya, M.C.M.; Borges, A.C. \& Araújo, E.F. 2005b. Morphological and molecular characterization of mycorrhizal fungi isolated from neotropical orchids in Brazil. Canadian Journal of Botany 83: 54-65.

R Developmet Core Team 2013. R: A language and environment for statistical computing. R Foundation for Statistical Computing, Vienna, Austria. Available in: http://www.R-project.org/. Accessed in: 3 September 2013.

Rasmussen, H.N. 1995. Terrestrial orchids: From seed to mycotrophic plants. London, CU Press.

Rasmussen, H.N. \& Whigham, D.F. 2002. Phenology of roots and mycorrhizae in orchid species differing in phototrophic strategy. New Phytologist 154: 797-807.

Rivas-Rozzi, M.; Warmer, J. \& Bermúdez, M. 1998. Presencia de micorrizas en orquídeas de un jardín botánico neotropical. Revista de Biología Tropical 46: 211-216.

Valadares, R.B.S.; Perotto, S.; Santos, E.C. \& Lambais, M.R. 2013. Proteome changes in Oncidium sphacelatum (Orchidaceae) at different trophic stages of symbiotic germination. Mycorrhiza, DOI 10.1007/ s00572-013-0547-2

Zettler, L.W.; Delaney, T.W. \& Sunley, J.A. 1998. Seed propagation of the epiphytic green-fly orchid, Epidendrum conopseum R. Brown, using its endophytic fungus. Selbyana 19: 249-253. 